\title{
Lexical Borrowing, Categorization, and Mental Representation
}

\author{
Attila Benő \\ Babeş-Bolyai University, Faculty of Letters \\ Hungarian and General Linguistics Department \\ attilabe@yahoo.com
}

\begin{abstract}
The article argues that lexical borrowing is not only motivated by cultural factors linked to prestige or economical aspects but also by the speakers' need for new lexical-semantic categories and for highly expressive metaphorical terms to operate with, which makes them borrow words. The semantic changes of the lexical borrowings point to the creation of new items in the semantic fields of the receiving language. The integration of borrowings into Hungarian and Romanian exemplifies these processes.
\end{abstract}

Keywords: word borrowing, lexical categorization, semantic change, representation, lexical codability

\section{Introduction}

Why do we borrow words from other languages? The simplistic approach regarding the motives of lexical borrowings concerns only cultural differences and the economic development of the source language community as well as the prestige associated with it (Benő 2008: 173-175). As all theoretical frameworks, such models formulate important and valid half-truths but do not provide an explanation regarding the complex nature of certain languages' layers of loanwords. The diversity seen in the parts of speech of loanwords (e.g. adjectives, verbs, interjections, sentence substitutes) indicates that borrowing does not only aim at words denoting realia or culture-specific concepts (usually in the form of nouns). In order to understand the complexity of the phenomenon, aspects such as phonetic and semantic expressivity (Benő 2000), categorization of meaning on the level of words, linguistic taboo and phonetic representation, the visual language environment, and pursuing economy in language use (Benő 2008: 173184) must be taken into consideration. 
In my article, I examine the correlations between lexical borrowings and language-specific lexical categorization in the context of the structure of the semantic field and creating new conceptual hierarchies of meaning.

\section{Cognitive content, semantic content, and representation}

Different languages divide reality differently by referring to the human environment with the unique conditions created by their grammatical and semantic systems. In this sense, language offers a point of view to the speakers. This language-specific way of seeing the world can highlight some characteristics of denotata, and thus it allows categorizing certain objects, attributes, and relations in a specific way. However, the linguistic view of the world should not be imagined as something predestined, the effect of which cannot be avoided by the speaker. Rather, in the context of language, we tend, "to perceive" certain connections and to emphasize the attributes of adjectives as they are represented by the linguistic point of view; however, by observation and thinking, we are able to rearrange these connections and to interpret them differently. From this perspective, cognitive content and semantic content can be differentiated, even if the two knowledge dimensions are interconnected. The cognitive content refers to the knowledge we gain through our senses and mental activity (thinking, imagination, etc.). The language forms the cognitive content into semantic content in a specific way, by "highlighting different facts in different arrangements, developing its own focal points in different places, giving them a different emphasis" (Hjelmslev 1975). The starting point of this deduction is Saussure, who argues that "the thought in itself is like a nebula, within which nothing is necessarily delimited. There are no pre-defined concepts, and nothing is separated until language appears" (Saussure 1916/1967: 144).

The categorization of colours is done differently by the different languages. However, colour perception develops its own system regardless of language. Even those speakers whose language does not have a lexicalized denominator for orange can, if necessary, distinguish orange from yellow. At the same time, it has been proven that colours have a basic shade (focus), which is the same for all people, regardless their language and culture. Thus, the shade of blood is the basic shade for red (Taylor 1989). Other shades compared to focus colours are interpreted as lighter or darker. The explanation of this universal phenomenon can also be found in the human perceptual processes. On this basis, it is necessary to distinguish the categories of linguistic and non-linguistic nature, even if these are closely related, so that we do not come to a conclusion which implies that without language only an inarticulate, blurred sensuous world is left behind. Even animals categorize despite lacking such an articulate communication tool as the 
human language (to such an extent that categorization becomes vital to them as well). Therefore, linguistic categorization should not be considered as something without which we would live confused by our senses but rather as a cognitive tool which allows sensory data to be more accurate, focusing on certain attributes, creating similarity relations on this basis, performing a secondary categorization on the sensory, memorial data. However, we cannot say that nothing is separated until language appears, but only that language transforms cognitive content into semantic content. And all languages do this differently.

The category as a mental unit is directly related to the conceptual meaning of the word and can be interpreted as a mental representation, as a cognitive structure, which represents in our minds a particular object of the outside world, the relation of the objects (Csépe-Győri-Ragó 2007-2008: 156-157). Language in this respect can be considered a representation tool, which primarily "represents" the outside world to us, playing an active role in the perception of the elements and the relations of our environment based on our categories and in the way we notice the things we know about. Therefore, we can say that all languages represent an interpretation perspective (Bańczerowski 1999: 194).

\section{Semantic field and lexical coding}

Semantic content is not an indefinable information block, but it is organized into languages as a system. This can be seen from the level of bound morphemes to the structuring of phrases. It has been observed on the level of lexemes that elements with similar meanings have a relationship of interdependence and are organized into semantic fields. In the traditional Trierian sense, the semantic field refers to a semantically related group of words in which the lexemes fully cover a subdivision of reality divided between each other (Telegdi 1977: 144149, Péntek 1988: 63-65, Károly 1970: 60-61, A. Jászó 1991: 445-451). This idea based on mosaic-like representation should not be interpreted as if in the categorization system there was no more space left and no demand for a more nuanced classification of meaning, filling in the existing gaps in the vocabulary. The elements of the semantic field do not create all the possible combinations of the conceptual attributes: different denotations are referred to with the same word of a somewhat more general meaning; but we could refer to a signified from other languages, which, although referring to the same semantic field, do not match any of the existing lexemes. As shown later, such "deficiencies" of the semantic field can be the motivators of lexical borrowings if there is an existing lexicalized form for this narrower meaning in the source language.

In the English scholarly literature, within the semantic field, word field and lexical field are distinguished (Asher 1994: 2144-2146, Faber-Mairal 1997). This 
distinction indicates whether the semantic field is morphologically composed of simple or more complex elements (compound word, idiom, etc.). Word field is used to denote semantic fields composed of simple elements, while lexical field includes not only formally simple but also compound lexemes. The validity of the distinction can be seen in the importance of whether a signified in a certain language or dialect is referred to with a simple word or a compound word or a lexicalized syntagm. On the one hand, the simple word merely names it, while the compound word somehow qualifies, characterizes the concept. (A good example of this is the case of salt and sodium chloride. Salt represents the concept in its everyday existence, while sodium chloride also refers to its chemical composition. On this basis, the two names can serve as the starting point of different associations.)

Lexicalized language units (mainly simple and compound words) represent concepts that are common to us, have become units of common thinking, and do not need to be created by creative thinking. Psychological research indicates that lexicalized concepts are more striking and easier to learn (Csépe-Győri-Ragó 2007-2008: 156-157).

This is linked to lexical coding, to the phenomenon of conceptual meanings condensed into the linguistic signs at the word level within a certain language, of what can be expressed with a lexical unit and what can be referred to only with syntactic structures or description (cf. Proost 2007: 92). As words refer to concepts and concepts are the basic units of our thinking, the way we think about our problems and perceive the phenomena are obviously affected by lexical coding.

\section{Lexical borrowings, modification of semantic field, and representation}

As a result of the spread and adaptation of borrowings, the semantic fields of language become further articulated, and more nuanced possibilities of categorization emerge. The enrichment of the semantic fields of colours illustrates this phenomenon in the case of numerous languages. Languages usually do not borrow words denoting basic colours since elements from the vocabulary of the basic language describe these, but they borrow words used to indicate different shades of the basic colours. This also can be illustrated with the borrowed names of colours in Hungarian:

Hung. bordó "dark red, wine red" (bordóvörös) < Ger. bordeaux(rot) < Fr. bordeaux "dark red wine" (Bordeaux, town);

Hung. cinóber "vermilion" < Ger. Zinnober Id.; 
Hung. mahagóni < Sp. mahogani 'tropical tree species', 'the reddish colour of this' (from the language of Caribbean or Maya Indians);

Hung. karmazsin 'deep, slightly bluish red' < It. carnesin Id.;

Hung. karmin 'slightly reddish purple' < Ger. Karmin or It. carmin;

Hung. indigó ‘vivid blue colour' < Ger. indigo < Sp. indigo Id. < Lat. indicum < Gr. Indikon 'Indian';

Hung. azúr 'azure' < Ger. Azur < It. Azzuro 'Id.' < lat. (lapis) lazuli 'bluestone, vivid-blue mineral';

Hung. lilla < Ger. lila < Fr. lilas 'lilac';

Hung. bézs 'tawny, greyish-yellow, beige' < Fr. beige < It. bigio 'greyish-brown' $<$ Lat. bysius Id..

This peripheral nature of the colour names in relation to the basic colours can be seen among the loanwords used in standard Romanian:

Rom. bej 'beige' < Fr. Beige,

Rom. bordo < Fr. Bordeaux,

Rom. oranj 'orange'< Fr. Orange,

Rom. lila 'purple' < Fr. lilas,

Rom. ultramarin < Ger. Ultramarin,

Rom. violet 'hyacinth'< Fr. violet,

Rom. gri 'grey' < Fr. gris,

Rom. maro 'brown' < Fr. maron.

With such lexical borrowings, the semantic structure of the semantic field of the colour names in the receiving language will become more articulated. Sometimes, compared to the etymon, the meaning of colour names is modified by narrowing of meaning or metonymic contact in the receiving language or dialect, also to create a new category of colour names on the level of simple words, as it can be illustrated with data from several languages:

Hung. rót 'brownish-red, reddish' < Ger. (Bavarian-Austrian) röt 'red, blood';

Hung. sziéna 'reddish-brown' < It. Siena (town);

Eng. khaki < Urdu kháki 'dusty', 'dust-coloured’;

It. scarlatto 'scarlet'< Farsi szakalát 'purpure';

Lat. ochra 'ocher (yellow)' < Gre. ókhra 'yellow earth';

Lat. sepia 'reddish-brown' < Gre. szépia 'cuttlefish', 'the secretion of the cuttlefish';

Rom. dial. barna 'dark brown' < Hun. barna 'brown';

Rom. dial. şargă 'pallid, greyish-yellow' < Hun. sárga 'yellow’

One of the most common types of semantic change of the borrowings is narrowing of meaning, creating specific meanings (Péntek 1981, Benő 2014: 113-115), which adds new categories of meaning to the matching semantic field. The reason for the narrowing of meaning is often focusing on the physical properties (size, material) or function of the signified objects. The highlighted 
attribute becomes the basis of the narrowing of meaning, as shown below by the Hungarian borrowings adapted in Romanian dialects in Transylvania:

Hung. tó 'lake' > Rom. dial. tău 'smaller lake',

Hung. ablak 'window' > Rom. dial. obloc 'wooden window',

Hugn. csésze 'cup' > Rom. dial. cesă 'porcelain cup',

Hung. papír 'paper' > Rom. dial. popir 'rolling paper',

Hung. leves 'soup' > Rom. dial. leves 'broth'.

Meanings formed this way create new functional categories of word-meaning in the semantic system of the receiving language.

The enrichment of semantic fields and the number of synonyms as the result of lexical borrowings is allowed not only by the introduction of lexical elements denoting new concepts or the change in the conceptual precision of lexical meanings but also by the form of the value of expressivity, which is linked to the metaphorical meaning of the borrowings and which can have a role in spreading and adapting the borrowing.

Hung. bifláz 'to mug up, to learn by rote' < Ger. büffeln Id. (to work like a buffalo);

Hung. kalamajka 'mess', 'foolish, half-witted' < Ukr. kolomijka 'fast Ukrainian dance';

Hung. krapek 'fella, dude, covey' (pej.) < Slk. chlapík 'man, good fellow';

Hung. kupec 1. 'merchant'; 2. 'cunning, swindler' <Slk. kupec 'customer'; (old) 'merchant';

Hung. dial. in Trans. botyezál 'to dilute wine or milk with water' < Rom. a boteza 'baptize';

Hung. slang in Trans. tocsilár 'plodding student' < Rom. tocilar 1. 'grinder'; 2. 'plodding student';

Hung. slang smeker 'cunning, skilful, circumventing rules' < Rom. şmecher 1. 'vulpine, sharp, cunning; 2. clever, witty, ingenious' < Ger. Schmecker 'wine tasting'. ${ }^{1}$

The motive behind such expressivity in metaphorical meaning can be, by borrowing a word and adapting it to a given dialect, enriching the structure of meaning of a concept with a lexeme denoting stylistic and expressive value. The data quoted above indicates that sometimes the new categories of meaning are a result of pejorative change of meaning (botyezál, kalamajka, krapek, kupec, smeker).

Sometimes, lexical borrowings of foreign origin not only allow the adoption of more nuanced conceptual meanings but also create wider and multiple association relations due to different conceptual representations. Our recent, informal word

1 Termini Hungarian Online Dictionary: Termini magyar-magyar szótár (http://ht.nytud.hu/ htonline). 
of English origin lúzer is not just a synonym for the Hungarian adjective vesztes 'loser'. When defining the meaning of lúzer, marks that indicate the surplus of meaning compared to our word vesztes refer to: "a person who is essentially incapable of self-realization or achieving any kind of success, with a hopeless life and bleak future"; "It is used to describe a man who does not succeed in anything". ${ }^{3}$ The word vesztes can denote a current state: yesterday's loser can be a winner today. The word lúzer refers to an unsuccessful person living a lousy life, carrying this burden all his/her life. The network of meaning of the word lúzer is based on a reductive view according to which there are people who are successful in all areas of life, every step of their lives, and in the same way there are unsuccessful, losing people in every respect. This contrastive lexical and conceptual categorization based on excessive generalization and simplification does not take into account the fact that the people considered to be successful have inevitably faced loss, while the people considered to be unsuccessful losers could get into a winning position in some way, and no one can be considered to be completely unsuitable for a certain successful activity. The verbal form of the adjective lúzer was created with a verbal prefix, and its meaning is becoming wider as it can be used to belittle almost anyone: Vajna Tímea lelúzerezte a melósokat ([Hungarian celebrity] Tímea Vajna called the toilers lúzer). ${ }^{4}$

Similarly, the Hungarian balek 'gullible, credulous person' (< Tur. balik 'fish', 'an easily hooked fish') refers not only to momentary deceptiveness or credulity, but it represents an unalterable character defect and stigmatizes an attitude towards a given situation of reality: the category of meaning of the word has the outcome that there are people acting as a balek, while others do not act as a balek; as if a particular way of approaching was inevitably given, and the person was not able to change his/her attitude. But who is the one who has never proved to be gullible or credulous?

Similarly, an attitude is displayed as a type of human being by the word frájer in the Hungarian slang in Transylvania, which is a Romanian-mediated German word: frájer 'dumb, credulous, gullible person' < Rom. fraier Id. < Ger. freier 'fiancé, suitor'. ${ }^{5}$ This is more pejorative than the frajer used in the Hungarian slang with the meaning of 'cool, pompous', ${ }^{6}$ which originates directly from German.

2 https://hu.wikipedia.org/wiki/Lúzer.

3 http://idegen-szavak-szotara.hu.

4 http://www.borsonline.hu/celeb/vajna-timea-leluzerezte-a-melosokat/94382.

5 Termini magyar-magyar szótár (http://ht.nytud.hu/htonline).

6 http://idegen-szavak-szotara.hu. 


\section{Summary}

Among the motives of lexical borrowing and lexical adaptation, we have to take into consideration the more nuanced demand for categorization. Lexical borrowings integrating this way further articulate the structure of the given semantic field. The processes of changing the meaning of the borrowings is functional: they usually allow developing new categories of word meaning and often represent added values of expressivity. The borrowing among the synonyms of the receiving language sometimes refers to its signified with a particular linguistic representation, which may also be a motive for its adaptation.

\section{References}

Asher, Ron E. (ed.). 1994 The encyclopedia of language and linguistics. vol. 1-10. Oxford-New York-Seoul-Tokyo: Pergamon Press.

Bańczerowski, Janusz. 1999. A világ nyelvi képe mint a szemantikai kutatások tárgya. Magyar Nyelv 2: 188-194.

Benő, Attila. 2000. Az expresszivitás változásai román eredetű kölcsönszavainkban. Magyar Nyelv 4: 436-445.

2014. Kontaktusjelenségek az erdélyi magyar nyelvváltozatokban. Kolozsvár: Erdélyi Múzeum-Egyesület.

2008. Kontaktológia. A nyelvi kapcsolatok alapfogalmai. Kolozsvár: Egyetemi Mühely Kiadó-Bolyai Társaság.

Csépe, Valéria-Győri, Miklós-Ragó, Anett. 2007-2008. Általános pszichológia 1-3. - 2. Tanulás - emlékezés - tudás. Budapest: Osiris Kiadó.

Faber, Pamela-Mairal, Ricardo. 1997. The paradigmatic and syntagmatic structure of the semantic field of existence in the elaboration of a semantic macronet. Studies in Linguistics 21(1): 129-167.

Hjelmslev, Louis. 1975. A jel szerkezete. In: Horányi, Özséb-Szépe, György (eds), A jel tudománya. Budapest: Gondolat. 189-205.

A. Jászó, Anna (ed.). 1991. A magyar nyelv könyve. Budapest: Tankönyvkiadó.

Károly, Sándor. 1970. Általános és magyar jelentéstan. Budapest: Akadémiai Kiadó.

Péntek, János. 1981. A román-magyar nyelvi kölcsönhatás néhány szemantikai vonatkozása. Nyelv- és Irodalomtudományi Közlemények XXV: 77-81.

1988. Teremtô nyelv. Bukarest: Kriterion.

Proost, Kristel. 2007. Conceptual structure in lexical items. Amsterdam-Philadelphia: John Benjamins Publishing Company.

Saussure, Ferdinand. 1916/1967. Bevezetés az általános nyelvészetbe. Budapest: Gondolat Könyvkiadó. 
Taylor, John R. 1989. Linguistic Categorization. Prototypes in Linguistic Theory. Oxford: University Press.

Telegdi, Zsigmond. 1977. Bevezetés az általános nyelvészetbe. Budapest: Tankönyvkiadó. 